\title{
CRYSTALLINE INCLUSIONS AND C-ISOTOPE RATIOS IN DIAMONDS FROM THE SNAP LAKE/KING LAKE KIMBERLITE DYKE SYSTEM: EVIDENCE OF ULTRADEEP AND ENRICHED LITHOSPHERIC- MANTLE
}

\author{
Nikolai Pokhilenko ${ }^{1,2}$, John McDonald ${ }^{2}$, Nikolai Sobolev ${ }^{1}$, Vadim Reutsky ${ }^{3}$, Anne Hall ${ }^{2}$, \\ Alla Logvinova ${ }^{1}$, and Lada Reimers ${ }^{2}$ \\ ${ }^{1}$ Institute of Mineralogy and Petrography, Novosibirsk, Russia; ${ }^{2}$ Diamondex Resources Ltd., Vancouver, Canada; ${ }^{3}$ \\ United Institution of Geology, Geophysics and Mineralogy, Novosibirsk, , Russia
}

\section{INTRODUCTION}

The Snap Lake/King Lake (SL/KL) kimberlite dyke system of the southern Slave Craton, Canada was discovered in 1997 by Canadian junior exploration company, Winspear Resources Ltd. An abnormal thickness of lithosphere beneath the SL/KL area is indicated by: (1) an abnormally wide range of $\mathrm{Cr}_{2} \mathrm{O}_{3}$ content and character of the REE distribution in pyropes, (2) a very high proportion of high-Cr chromites, and (3) some other specific geochemical and isotope characteristics of the SL/KL kimberlite system (Pokhilenko et al., 1998, 2000, 2001, 2003; Agashev et al., 2001; McLean et al., 2001). Preliminary results from study of the SL/KL diamonds, and their crystalline inclusions, reveals increased ${ }^{13} \mathrm{C}$ isotopic compositions in the $\mathrm{SL} / \mathrm{KL}$ diamonds, as well as providing additional evidence to suggest that a relatively enriched and abnormally thick lithosphere lies beneath the Southern Slave Craton (Pokhilenko et al., 2001; Reutsky et al., 2002). This paper contains the results of a more detailed study of the crystalline inclusions and C-isotope compositions of a representative collection of the SL/KL diamonds.

\section{METHODS}

Major-element data on crystalline inclusions have been obtained with a Cameca CAMEBAX-Micro Electron microprobe, using a wide range of natural minerals and synthetic glasses for standards, at the Analytical Center of the United Institute of Geology, Geophysics and Mineralogy, Siberian Branch of Russian Academy of Sciences. All the C-isotope analyses were carried out at the same Analytical Center, using a Finnigan-MAT Delta mass spectrometer with a typical precision of $0.2 \%$. Methods and techniques for the preparation and carbon isotope analysis is described in detail by
Reutsky et al. (1999). Isotopic composition is given in delta notation (parts per thousand) as the deviation from the VPDB standard.

\section{MINERAL INCLUSIONS IN SL/KL DIAMONDS}

Mineral inclusions from 115 diamond crystals (-4 $+2 \mathrm{~mm}$ size) obtained from the SL/KL kimberlites have been studied. Approximately $75 \%$ of the diamonds are colorless octahedrons, while the rest are crystals of transitional shape (octahedron - dodecahedron) and spinel twins. Crystals of pale smoky brown and greenish tint were rare in the study group. Inclusions of U-type minerals predominate, occurring in $94.7 \%$ of the diamonds. The most common inclusions (number of diamonds are listed in brackets) are olivine (90; up to 5 separate inclusions in some diamonds) and enstatite (22). Sulphide, Cr-pyrope, chromite and $\mathrm{Cr}$-diopside inclusions are less abundant $(15,10,5$ and 1, diamond respectively). Different U-type mineral inclusions coexisting in one diamond are: olivine + sulfide $(9$ diamonds), olivine + enstatite (8), pyrope + olivine (4), chromite + sulfide (2), pyrope + olivine + enstatite $(2)$, chromite + olivine + enstatite $(1)$, olivine + chromite (1), pyrope + sulfide (1) and enstatite + Cr-diopside (1).

E-type mineral inclusions are represented by clinopyroxene (5 diamonds), garnet (2) and sulfide (1) with the following associations noted in single diamonds: garnet + clinopyroxene + sulfide $(1)$ and garnet + clinopyroxene (1).

\section{OLIVINE INCLUSIONS}

Olivine inclusions observed in 90 diamonds are characterized by a relatively narrow range of composition: about $80 \%$ of them have $\mathrm{Mg \#}$ $[100 \mathrm{Mg} /(\mathrm{Mg}+\mathrm{Fe})]$ ranging from 91.8 to 93.0 . A single inclusion has $\mathrm{Mg \#}$ less than $91\left(\mathrm{SL}_{5}-44=90.7\right)$, and 
olivine inclusions in two diamonds have $\mathrm{Mg \#}$ higher than $93\left(\mathrm{SL}_{3}-20=93.6 ; \mathrm{SL}_{5}-14=94.8\right)$. The $\mathrm{NiO}$ content varies from 0.29 to 0.40 wt. $\%$, with over $80 \%$ between 0.33 to 0.37 wt. $\%$. The $\mathrm{Cr}_{2} \mathrm{O}_{3}$ ranges from 0.01 to 0.07 wt.\%, and $\mathrm{CaO}$ from 0.01 to 0.05 wt.\% (Table 1).

\section{Table 1: Representative analyses of olivine, enstatite and chromite inclusions in SL/KL diamonds}

\begin{tabular}{lllll} 
Sample & $\mathrm{SL}_{3}-20$ & $\mathrm{SL}_{3}-31$ & $\mathrm{SL}_{3}-\underline{8}$ & $\mathrm{SL}_{5}-\underline{-4}$ \\
\hline Mineral & & Olivine & & \\
\hline $\mathrm{SiO}_{2}$ & 41.00 & 41.70 & 41.40 & 41.00 \\
$\mathrm{TiO}_{2}$ & nd & nd & nd & nd \\
$\mathrm{Al}_{2} \mathrm{O}_{3}$ & nd & nd & nd & nd \\
$\mathrm{Cr}_{2} \mathrm{O}_{3}$ & 0.02 & 0.07 & 0.02 & 0.07 \\
$\mathrm{FeO}$ & 6.34 & 7.51 & 7.64 & 9.09 \\
$\mathrm{MnO}$ & 0.10 & 0.11 & 0.10 & 0.13 \\
$\mathrm{MgO}$ & 52.10 & 50.20 & 50.20 & 49.50 \\
$\mathrm{CaO}$ & 0.01 & 0.03 & 0.02 & 0.01 \\
$\mathrm{NiO}$ & 0.29 & 0.34 & 0.35 & 0.37 \\
$\mathrm{Na}{ }_{2} \mathrm{O}$ & nd & nd & nd & nd \\
$\mathrm{Total}$ & 99.9 & 100.0 & 99.7 & 100.2 \\
$\mathrm{Mg \#}$ & 93.6 & 92.3 & 92.2 & 90.7
\end{tabular}

\begin{tabular}{llllll}
$\mathrm{SL}_{5}-96$ & $\mathrm{SL}_{3}-12$ & $\mathrm{SL}_{5}-100$ & $\mathrm{SL}_{5}-64 a$ & $\mathrm{SL}_{5}-64 \mathrm{bSL}$ \\
\hline Enstatite & & \multicolumn{5}{c}{ Chromite } \\
\hline 57.3 & 58.4 & 58.0 & 0.26 & 0.24 & 0.09 \\
$<0.01$ & $<0.01$ & $<0.01$ & 0.09 & 0.11 & 0.11 \\
0.68 & 0.41 & 0.35 & 12.5 & 4.79 & 7.37 \\
0.49 & 0.33 & 0.26 & 55.6 & 64.4 & 63.3 \\
3.98 & 4.69 & 6.29 & 15.5 & 15.3 & 13.6 \\
0.08 & 0.12 & 0.15 & 0.12 & 0.19 & 0.17 \\
36.4 & 36.1 & 33.4 & 14.3 & 13.8 & 14.4 \\
0.16 & 0.35 & 0.42 & nd & nd & nd \\
0.11 & 0.10 & 0.07 & 0.13 & 0.13 & 0.11 \\
0.02 & 0.06 & 0.03 & nd & nd & nd \\
99.2 & 100.5 & 99.0 & 98.5 & 99.0 & 99.2 \\
94.2 & 93.2 & 90.4 & 62.2 & 61.6 & 65.4
\end{tabular}

\section{ENSTATITE INCLUSIONS}

Twenty enstatite inclusions have been analyzed and most have a narrow range of composition. For 16 inclusions the $\mathrm{FeO}$ content varies from 4.40 to 4.80 wt.\%, with the other 4 falling outside this range (3.97, $3.98,4.34$ and 6.29 wt.\% respectively, Table 1). $\mathrm{Al}_{2} \mathrm{O}_{3}$ content for 18 inclusions varies from 0.4 to $0.6 \mathrm{wt} \%$ (Fig. 1). An enstatite from an enstatite-Cr-diopside intergrowth $\left(\mathrm{SL}_{5}-100\right.$, Table 1$)$ has the minimum $\mathrm{Al}_{2} \mathrm{O}_{3}$ (0.35 wt.\%) and $\mathrm{Cr}_{2} \mathrm{O}_{3}(0.26$ wt.\%) contents, and maximum $\mathrm{CaO}(0.42$ wt.\%) values. The maximum $\mathrm{Al}_{2} \mathrm{O}_{3}$ content ( 0.68 wt.\%), from sample $\mathrm{SL}_{5}-96$ (Table
1), also has maximum $\mathrm{Cr}_{2} \mathrm{O}_{3}(0.49$ wt.\%) and minimum $\mathrm{CaO}(0.16$ wt.\%) values. The majority of enstatite inclusions have $\mathrm{Cr}_{2} \mathrm{O}_{3}$ and $\mathrm{CaO}$ contents between 0.30 and 0.40 wt. $\%$, and $\mathrm{Na}_{2} \mathrm{O}$ values between 0.02 and 0.06 wt.\%.

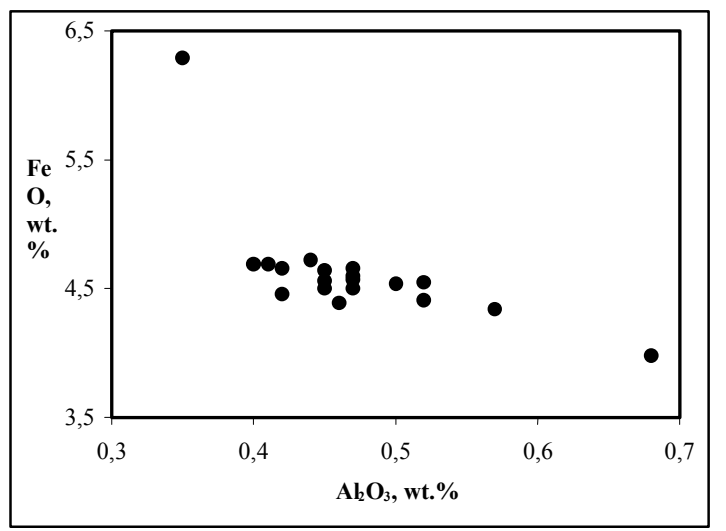

Figure 1. Plot of $\mathrm{FeO}$ vs $\mathrm{Al}_{2} \mathrm{O}_{3}$ for enstatite inclusions in the Snap Lake diamonds.

\section{CHROMITE INCLUSIONS}

Six chromite inclusions were identified in 5 diamonds: Chromite was found in association with sulphides (2 diamonds), with olivine (1) and as an intergrowth with olivine and enstatite (1). One diamond, ( $\mathrm{SL}_{5}-64 \mathrm{a}, \mathrm{b}$, Table 1), had only 2 chromite inclusions with significantly different compositions: $\mathrm{Cr}_{2} \mathrm{O}_{3}-55.60$ and 64.40 wt. $\% ; \mathrm{Al}_{2} \mathrm{O}_{3}-12.50$ and 4.79 wt. $\%$; and $\mathrm{MgO}-$ 14.30 and 13.80 wt.\% respectively. In two of the diamonds, the chromites have unusual, relatively low $\mathrm{Cr}_{2} \mathrm{O}_{3}$ (55.60 and 59.10 wt.\%) contents. All the inclusions have low $\mathrm{TiO}_{2}$ content (0.05-0.11 wt.\%).

\section{GARNET INCLUSIONS}

Ten Cr-pyrope, and two E-type garnet inclusions were analyzed (Table 2). For the Cr-pyropes, $\mathrm{Cr}_{2} \mathrm{O}_{3}$ values vary from 7.71 to 12.8 wt.\%, $\mathrm{CaO}$ from 3.7 to 5.75 wt. $\%, \mathrm{TiO}_{2}$ from $<0.01$ to 0.19 wt. $\%$, and $\mathrm{Mg \#}$ from 82.9 to 86.7. Two Cr-rich, high-Mg, subcalcic pyrope inclusions of harzburgite paragenesis $\left(\mathrm{SL}_{3}-31\right.$ and $\mathrm{SL}_{3}-$ 30 , Table 2), have significant excess of $\mathrm{Si}$, indicating the presence of a majorite component (11.6 and 16.8 mol.\%). Both E-type garnet inclusions also contain this majorite component (5.0 and $6.1 \mathrm{~mol} \%$, Table 2), and have a $\mathrm{Na}_{2} \mathrm{O}$ content of 0.33 and 0.38 wt.\%.

\section{CLINOPYROXENE INCLUSIONS}

Clinopyroxene (cpx) inclusions were found in 6 diamond crystals, 5 of which contained E-type cpx. All of these are omphacitic (jadeite component of 29.4 to 36.2 mol.\%; Mg\# - 66.5 to 75.8), with elevated $\mathrm{TiO}_{2}$ 
values of up to 0.49 wt. $\%$. Of special interest is the significant amount of $\mathrm{K}_{2} \mathrm{O}$ in the cpx: two discrete inclusions in a single diamond $\left(\mathrm{SL}_{5}-52\right)$ contain 1.27 and 1.37 wt. $\% \mathrm{~K}_{2} \mathrm{O}$. A single inclusion of U-type cpx has an unusual composition: $\mathrm{K}_{2} \mathrm{O}$ content $(0.71 \mathrm{wt} . \%)$ is significantly higher than the $\mathrm{Na}_{2} \mathrm{O}(0.42$ wt.\%) content, making this inclusion unique among previously studied U-type cpx inclusions in diamonds.

Table 2: Representative analyses of U-, Etype garnet and cpx inclusions in SL/KL diamonds

\begin{tabular}{lclllll} 
Sample & $\mathrm{SL}_{3}-12$ & $\mathrm{SL}-133$ & $\mathrm{SL}_{5}-5$ & $\mathrm{SL}_{3}-31$ & $\mathrm{SL}_{3}-30$ \\
\hline Mineral & \multicolumn{5}{c}{ U-type garnets } \\
\hline $\mathrm{SiO}_{2}$ & 41.3 & 41.2 & 42.0 & 42.2 & 42.3 \\
$\mathrm{TiO}_{2}$ & 0.13 & 0.05 & 0.06 & 0.19 & 0.06 \\
$\mathrm{Al}_{2} \mathrm{O}_{3}$ & 15.2 & 16.7 & 17.2 & 12.3 & 9.46 \\
$\mathrm{Cr}_{2} \mathrm{O}_{3}$ & 10.2 & 7.71 & 8.37 & 11.8 & 12.8 \\
$\mathrm{FeO}$ & 6.50 & 7.38 & 6.06 & 6.52 & 7.64 \\
$\mathrm{MnO}$ & 0.32 & 0.33 & 0.28 & 0.32 & 0.33 \\
$\mathrm{MgO}$ & 21.1 & 20.0 & 22.2 & 21.1 & 21.2 \\
$\mathrm{CaO}$ & 4.76 & 5.7 & 3.73 & 4.68 & 5.11 \\
$\mathrm{Na}_{2} \mathrm{O}$ & 0.03 & 0.02 & $<0.01$ & 0.03 & 0.01 \\
$\mathrm{~K}_{2} \mathrm{O}$ & - & - & - & - & - \\
$\mathrm{Total}$ & 99.5 & 99.1 & 99.9 & 99.1 & 99.0 \\
$\mathrm{Mg \#}$ & 85.2 & 82.9 & 86.7 & 85.2 & 83.2 \\
$\mathrm{Mj}, \mathrm{mol} . \%$ & 0.9 & 2.2 & 2.3 & 11.6 & 16.8
\end{tabular}

\begin{tabular}{|c|c|c|c|c|c|}
\hline \multirow{2}{*}{\multicolumn{2}{|c|}{$\frac{\mathrm{SL}_{5}-6 \quad S L_{5}-86}{\text { E-type garnets }}$}} & \multirow{3}{*}{$\frac{S L_{5}=-100}{\frac{U-t . C p x}{55.4}}$} & \multicolumn{3}{|c|}{$\mathrm{SL}_{5} \underline{-86} \mathrm{SL}_{5} \underline{-6} \mathrm{SL}_{5} \underline{-52 a}$} \\
\hline & & & E-typ & $\operatorname{cpx}$ & \\
\hline 42.1 & 40.1 & & 55.0 & 55.9 & 55.1 \\
\hline 0.44 & 1.44 & $<0.01$ & 0.49 & 0.45 & 0.48 \\
\hline 21.7 & 19.9 & 0.82 & 7.42 & 8.52 & 0.82 \\
\hline 0.07 & 0.02 & 1.36 & 0.02 & 0.09 & 0.04 \\
\hline 15.5 & 20.2 & 2.53 & 8.18 & 6.73 & 5.64 \\
\hline 0.34 & 0.36 & 0.12 & 0.10 & 0.12 & 0.06 \\
\hline 16.6 & 7.19 & 16.7 & 9.10 & 11.8 & 9.27 \\
\hline 3.03 & 10.6 & 21.2 & 15.0 & 9.20 & 14.1 \\
\hline 0.33 & 0.38 & 0.42 & 4.16 & 5.16 & 4.53 \\
\hline 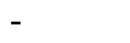 & - & 0.71 & 0.03 & 0.23 & 1.37 \\
\hline 100.1 & 100.2 & 99.3 & 99.5 & 98.2 & 99.3 \\
\hline 65.5 & 38.8 & 92.2 & 66.5 & 75.8 & 74.6 \\
\hline 5.0 & 6.1 & & & & \\
\hline
\end{tabular}

\section{C-ISOTOPE COMPOSITION}

The C-isotope composition has been determined for 34 diamonds with U-type inclusions (olivine, enstatite), 1 diamond with E-type inclusions (garnet $+\mathrm{cpx}$ ), and 4 diamonds without inclusions. The U-type diamonds show a range from $\delta^{13} \mathrm{C}-3.2$ to $-9.0 \%$, with an average of $-4.02 \%$. The E-type diamond has a $\delta^{13} \mathrm{C}$ of $-13.4 \%$.
When presented on a frequency histogram there is a strong peak at $\delta^{13} \mathrm{C}-3.5 \%$, which is significantly heavier compared to U-type diamonds from Siberia and South Africa (near - $4.5 \%$ ). The studied diamonds can be divided into two groups based on their $\mathrm{C}$-isotope composition, and $\mathrm{Mg} \#$ (Fig. 2) and $\mathrm{Ni} / \mathrm{Fe}$ ratio of their olivine inclusions. Most have a narrow variation of $\delta^{13} \mathrm{C}$ from -3.2 to $-4.8 \%$ (average $-3.72 \%$ ) and olivine inclusions with $\mathrm{Mg} \#$ less than 92.3 and relatively high $\mathrm{Fe} / \mathrm{Ni}$ ratios. A small group is characterized by a much wider variation of $\delta^{13} \mathrm{C}$ from -3.8 to $-9.0 \%$; (average $5.97 \%$ ), higher $\mathrm{Mg \#}$ (up to 93.6) and relatively low $\mathrm{Fe} / \mathrm{Ni}$ ratios of their olivine inclusions.

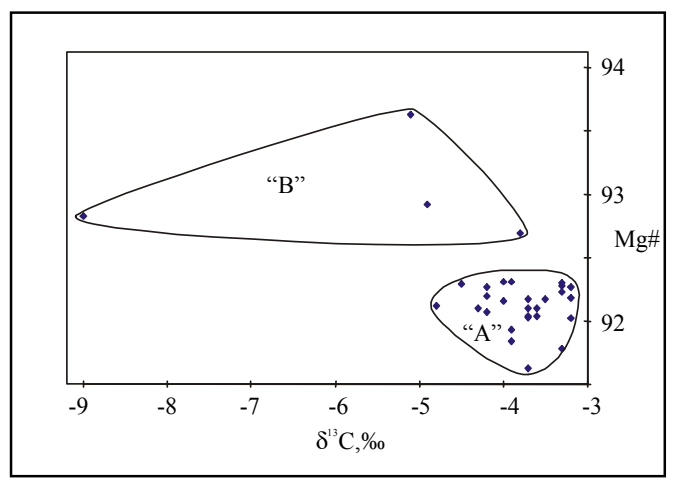

Figure 2. Variations of $\mathrm{Mg \#}$ in olivine inclusions vs. $\delta^{13} \mathrm{C}$ of diamond.

\section{DISCUSSION}

Previous petrological and mineralogical studies of mantle samples from the Slave Craton have produced a number of reliable results, suggesting a significant increase in lithosphere thickness towards the south of the craton: a) data obtained from mineralogical and petrological studies of SL/KL kimberlites and mineral inclusions in their diamonds, indicate that the lithosphere thickness beneath the SL/KL area was as much as $300 \mathrm{~km}$ at the time (Cambrian) of kimberlite emplacement (Pokhilenko et al., 1998, 2000, 2001); b) upper mantle xenolith studies have shown that the lithosphere thickness was $160-190 \mathrm{~km}$ in the northern part of the Slave Craton (Kopylova et al., 1999), 200 $\mathrm{km}$ for the central Slave (Pearson et al., 1999), and a minimum $230 \mathrm{~km}$ in the southern (Kennady Lake area) Slave Craton (Kopylova et al., 2001); c) evaluation of pyrope compositions from the Slave Craton kimberlites demonstrated a progressive increase of maximum $\mathrm{Cr}_{2} \mathrm{O}_{3}$ content in pyropes from the north to south of the craton (Grutter et al., 1999). 
The small proportion of E-type mineral inclusions in the $\mathrm{SL} / \mathrm{KL}$ diamonds is good evidence that depleted peridotites predominate in the SL/KL area lithospheric mantle, at depths corresponding to the diamond stability field. The presence of high-Cr high-Mg subcalcic pyrope inclusions in $\mathrm{SL} / \mathrm{KL}$ diamonds is definitely related to the diamondiferous depleted ultramafic rocks of the lithospheric mantle. From experiments modeling natural ultramafic systems, pressures of at least 110 kbar (corresponding to depths of over $300 \mathrm{~km}$ ) are required to achieve $\sim 16-17$ mol.\% dissolution of a majorite component into magnesian garnets (Irifune, 1987, Fig. 3). Other indications that some SL/KL diamonds were formed under very high pressures are: a) cpx inclusions with high $\mathrm{K}_{2} \mathrm{O}$ admixture in both Etype (up to 1.37 wt.\%) and U-type (0.71 wt.\%) parageneses; b) both E-type garnet inclusions contained significant $\mathrm{Na}_{2} \mathrm{O}$ admixture, and one of them $\left(\mathrm{SL}_{5}-6\right)$ has $\mathrm{Na}$ content $(0.046$ for 12 atoms of $\mathrm{O})$ significantly higher than $\mathrm{Ti}(0.024$ for 12 atoms of $\mathrm{O})$. Furthermore, an absence of $\mathrm{P}(<0.001$ for 12 atoms of $\mathrm{O})$ suggests that the reaction $\mathrm{R}^{2+} \mathrm{Al} \leftrightarrow \mathrm{NaSi}$ may occur, accompanied by partitioning of $\mathrm{Si}$ into octahedrally coordinated sites (Sobolev, Lavrent'ev, 1971).

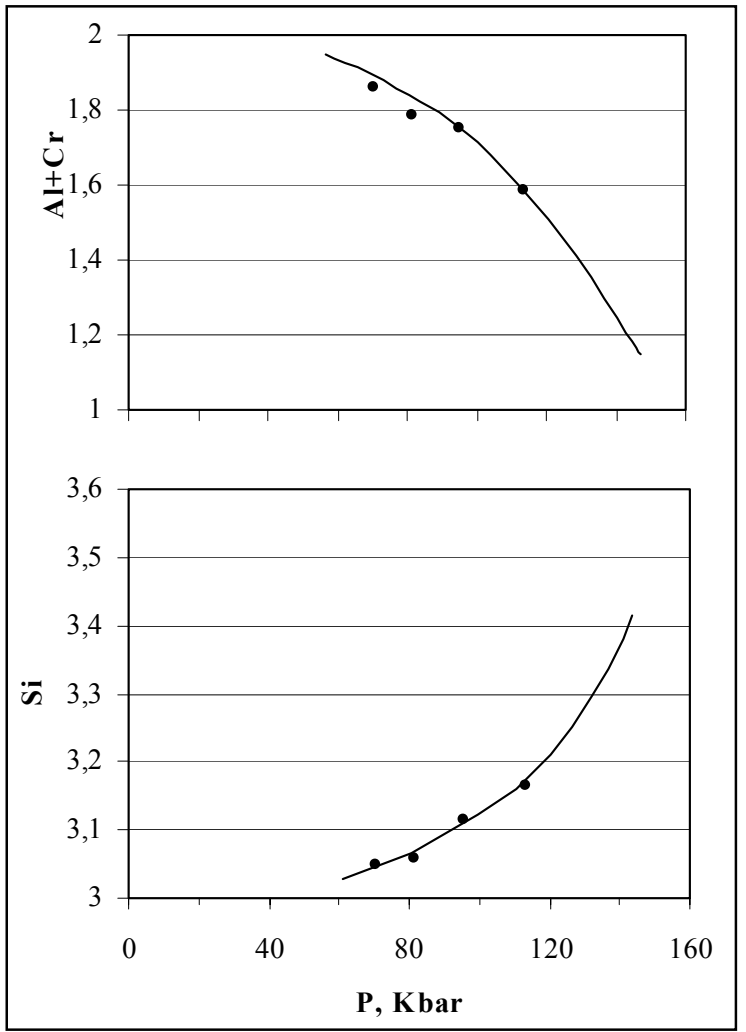

Figure 3. Distribution of $\mathrm{Al}+\mathrm{Cr}$ and $\mathrm{Si}$ (for 12 atoms of O) in garnet inclusions of SLK diamonds in relation with pressure parameters. Calibration curves from Irifune, 1987
The relatively low degree of both depletion and differentiation of ultramafic rocks comprising lithospheric mantle beneath SL/KL area is indicated by: a) relatively low $\mathrm{Mg \#}$ for olivine, enstatite and pyrope inclusions: b) a significantly higher average $\mathrm{CaO}$ content for $\mathrm{Cr}$-pyrope inclusions (4.6 wt.\%) compared to $\mathrm{CaO}$ contents of $\mathrm{Cr}$-pyrope inclusions in Siberian and South African diamonds; c) very uniform compositions of olivine and enstatite (Fig. 1, 4); and d) a comparative abundance of enstatite inclusions.

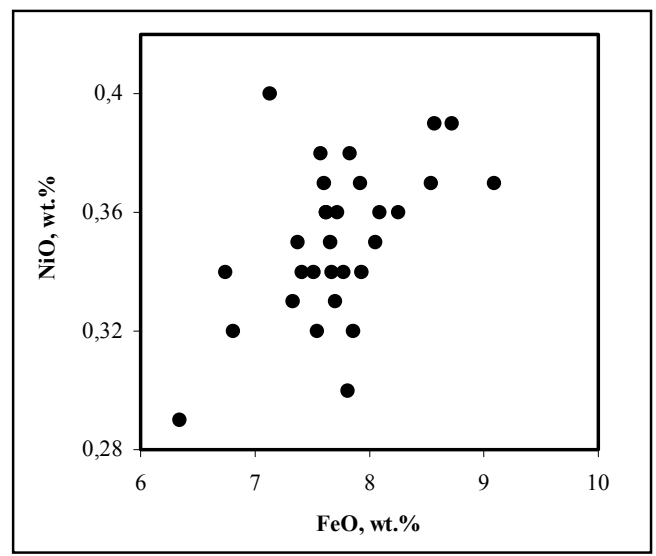

Figure 4. Plot of $\mathrm{NiO}$ vs $\mathrm{FeO}$ olivine inclusions in the Snap Lake diamonds

The C-isotope variations of the studied diamonds can be related to a number of reasons, including: a) peculiarities of asthenosphere degasation (Galimov, 1991) coupled with the abnormal thickness of the lithosphere; b) the abnormal thickness and relatively enriched character of the lithospheric mantle; and c) the involvement of subducted crustal $\mathrm{C}$ in the processes of diamond formation.

The formation of subcalcic Cr-pyrope inclusions with up to $17 \mathrm{~mol} . \%$ of majorite component is firm evidence of the existence of diamondiferous depleted peridotites of lithospheric mantle at depth $\sim 300 \mathrm{~km}$ beneath the $\mathrm{SK} / \mathrm{KL}$ area. This feature can be the most important among the main reasons for the much heavier $\mathrm{C}$ isotope composition of the SL/KL diamond population.

\section{REFERENCES}

Agashev, A.M., Pokhilenko, N.P., McDonald, J.A., Takazawa, E., Vavilov, M.A., Sobolev, N.V., Watanabe, T., 2001. A unique kimberlite-carbonatite primary association in the Snap Lake dyke system, Slave Craton: evidence from geochemical and isotopic 
studies. In: The Slave-Kaapvaal Workshop, Merrickville, Ontario, Canada.

Galimov, E.M., 1991. Isotope fractionation related to kimberlite magmatism and diamond formation. Geochim. Cosmochim. Acta 55, 1697-1708.

Grutter, H.S., Apter, D.B., Kong, J., 1999. Crust-Mantle Coupling: Evidence from mantle-derived xenocrystic garnets. In: Proc. $7^{\text {th }}$ Int. Kimberlite Conf., Cape Town, South Africa, 307-312.

Irifune, T., 1987. An experimental investigation of the pyroxene-garnet transformation and its bearing on the constitution of the mantle. Earth Planet Sci Lett 45, 324-336.

Kopylova, M.G., Caro, G., 2001. Lithospheric terranes of the Slave Craton: contrasting North and South. In: The Slave-Kaapvaal Workshop, Merrickville, Ontario, Canada.

Kopylova, M.G., Russell, J.K., Cookenboo, H., 1999. Mapping the lithosphere beneath the North Central Slave Craton. In: Proc. $7^{\text {th }}$ Int. Kimberlite Conf., Cape Town, South Africa, 468-479.

McLean, R.C., Pokhilenko, N.P., Hall, A.E., Luth, R., 2001. Pyropes and chromites from kimberlites of the Snap Lake area, Southeast Slave Craton: garnetization reaction of depleted peridotites at extremely deep levels of the lithospheric mantle. In: The SlaveKaapvaal Workshop, Merrickville, Ontario, Canada.

Pearson, N.J., Griffin, W.L., Doyle, B.J., O,Reilly, S.Y., van Achtenbergh, E., Kivi, K., 1999. Xenoliths from kimberlite pipes of the Lac de Gras area, Slave Craton, Canada. In: Proc. $7^{\text {th }}$ Int. Kimberlite Conf., Cape Town, South Africa, 307-312.

Pokhilenko, N.P., McDonald, J.A., Melnyk, W., Hall, A.E., Shimizu, N., Vavilov, M.A., Afanasiev, B.P., Reimers, L.F., Irvin, J., Pokhilenko, L.N., Vasilenko, V.B., Kuligin, S.S., Sobolev, N.V., 1998. Kimberlites of Camsell Lake Field and some features construction, and composition of lithosphere roots of southeastern part of Slave Craton, Canada. $7^{\text {th }}$ Int. Kimberlite Conf., Ext. Abstr., Cape Town, South Africa, 699701.

Pokhilenko, N.P., Sobolev, N.V., Cherny, E.D., Mityukhin, S.I., Yanygin, Yu. T., 2000. Pyropes and chromites from the kimberlites of Nakyn Field, Yakutia and Snap Lake region (Craton Slave, Canada): evidence for the anomalous lithosphere structure. Dokl. Akad. Nauk SSSR 372, 356-360 (in Russian).

Pokhilenko, N.P., Sobolev, N.V., McDonald, J.A., Hall, A.E., Efimova, E.S., Zedgenizov, D.A., Logvinova A.M., Reimers, L.F., 2001. Minerals inclusion in diamond from the Snap Lake (Craton Slave, Canada): new evidences for the anomalous lithosphere structure.

Dokl. Akad. Nauk SSSR 380(3), 374-379 (in Russian).

Reutsky, A.M., Pokhilenko, N.P., Hall, A.E., Sobolev, N.V., 2002. Polygenesis of diamonds from kimberlites of the Snap Lake region (Slave Craton, Canada): The results of $\mathrm{C}$ isotope composition and olivine inclusion study. Dokl. Akad. Nauk SSSR 386(1), 94-97 (in Russian).
Reutsky, V.N., Logvinova, A.M., Sobolev, N.V., 1999. Carbon isotope composition of the polycrystalline diamond aggregates with chromite inclusions from Mir kimberlite pipe, Yakutia. Geochemistry 11, 11911196 (in Russian).

Sobolev, N.V., Lavrent'ev, J.G., 1971. Isomorphic sodium admixture in garnets formed at high pressures. Contr. Miner. Petrol. 31, 1-12.

Contact: NP Pokhilenko, Institute of Mineralogy and

Petrography, 3 Koptyuga ave., Novosibirsk, 630090,

RUSSIA, E-mail: chief@uiggm.nsc.ru 